\title{
Prospecting for Nematodes Associated With Different Prunus Rootstocks in Brazil
}

\author{
Aline das G. Souza ${ }^{1}$, Andressa L. de Brida ${ }^{1}$, Flávio R. M. Garcia ${ }^{1} \&$ Valmor J. Bianchi ${ }^{1}$ \\ ${ }^{1}$ Federal University of Pelotas, Capão do Leão, RS, Brazil \\ Correspondence: Aline das G. Souza, Institute of Biology, Department of Botany, Federal University of Pelotas, \\ Campus Universitário, S/N., Caixa Postal 345, 96010-900 Capão do Leão, RS, Brazil. Tel: 55-959-9904-6104. \\ E-mail: souzaufpel@gmail.com
}

Received: April 23, 2019

doi:10.5539/jas.v11n11p253

\author{
Accepted: June 1, 2019 Online Published: July 31, 2019 \\ URL: https://doi.org/10.5539/jas.v11n11p253
}

\begin{abstract}
The aim of the present study was to carry out a search for phytonematodes to verify the abundance and frequency of nematodes present in a peach orchard at eight years of age. Soil and root samples from nine peach rootstocks were collected in an experimental area in the district of Capão do Leão, in the State of Rio Grande do Sul, Brazil. After extraction, the samples were evaluated under an optical microscope. Nematodes of the following genera were identified in the samples: Meloidogyne spp., Pratylenchus spp., Helicotylenchus spp., Mesocriconema spp., Trichodorus spp., Longydorus spp., Tylenchorchynchus spp., Hemiciclyophora spp., Xiphinema spp., Tylenchulus spp., Dorylaimus spp., Rotylenchulus spp. and Mononchus spp., all associated with the roots or soil rhizosphere of 'Aldrighi', 'Capdeboscq', 'Flordaguard', 'Nemaguard', 'Okinawa', 'Tusukuba', 'Umezeiro', 'Viamão' and 'Industry' rootstocks. The most frequent phytoparasitic nematodes were Meloidogyne spp., and Mesocriconema spp., which, under high populations or under inadequate management of the cultivated area, represent a risk to peach cultivation. Xiphinema and Pratylenchus are two other phytonematodes that can cause damage to peach trees and were identified in greater abundance in the 'Industry', 'Viamão' and 'Nemaguard' rootstocks. Under the conditions of the present research the 'Okinawa' and 'Umezeiro' rootstocks proved to be unfavourable hosts, especially for Meloidogyne spp. and Mesocriconema spp. The 'Viamão', 'Capdeboscq', 'Aldrighi' and particularly the 'Industry' rootstcks should not be recommended for use in areas with an incidence of the nematodes Meloidogyne spp. or Mesocriconema spp.
\end{abstract}

Keywords: horizontal distribution, Meloidogyne spp., Mesocriconema spp.

\section{Introduction}

The peach [Prunus persica (L.) Batsch] is one of the most-produced temperate fruits in the world, being highly appreciated both for in natura consumption, and in the canning industry, it is processed for pulp, jam, juice and nectar (Usda, 2018; Zhao, 2017). In 2015, Brazil ranked 13th in the world in terms of peach and nectarine production, with 218 thousand tons (FAO, 2018).

The State of Rio Grande do Sul stands out as the largest producer in Brazil, with approximately $61 \%$ of the planted area (IBGE, 2018), although it is still the state with the lowest average productivity, around 10 ton ha $^{-1}$ (Mayer et al., 2017).

The use of rootstocks with no genetic identity and susceptible to phytonematodes is one of the factors that has contributed to the low average productivity of peach orchards in Rio Grande do Sul (Mayer et al., 2017; Claverie et al., 2011). The occurrence of phytonematodes in stone-fruit trees has been associated with the decline of the plants in different producing regions around the world (Walters et al., 2008; Pinochet et al., 1996). In Brazil, there is a wide range of Prunus spp. rootstock introduced from other countries, each with a certain set of advantages and limitations for adaptation to different geographic regions (Almeida et al., 2015). Some cultivars are referred to as resistant to root-knot nematodes (Meloidogyne spp.), such as Nemared (Ramming \& Tanner, 1983), Flordaguard (Sherman et al., 1991), Guardian (Nyczepir et al., 1999), Okinawa (Paula et al., 2011), Umezeiro (Prunus mume) (Lecouls et al., 1997; Mayer et al., 2017) and MP-29 (Backman et al., 2012). Other genotypes with characteristics of interest are being investigated in Brazil, such as rootstocks of the Okinawa-roxo, Tsukuba 1, Tsukuba 2 and Tsukuba 3 cultivars (Souza et al., 2016; Souza et al., 2017a), as well as interspecific hybrids introduced and used successfully in other countries, and other species of Prunus spp. 
(Bianchi et al., 2004). However, few field studies have evaluated the potential of each of these genotypes under the conditions found in Brazil.

Given the importance of peach cultivation in Rio Grande do Sul, it is necessary to study the effective responses of the different rootstocks on population dynamics and the occurrence of phytoparasitic nematode species in stone fruits, not only under controlled conditions, but also under the conditions found in the field (Brida et al., 2017; Souza et al., 2017b).

Surveys of peach orchards in Rio Grande do Sul recorded a higher frequency of the species Meloidogyne javanica (Treub) Chitwood and M. incognita (Kofoid \& White) Chitwood in the root system of the peach trees (Campos et al., 2002). A similar occurrence was recorded by Ferreira et al. (2007) in peach orchards in the State of São Paulo, Brazil.

In addition to the peach trees (Prunus persica), different species of the genus Meloidogyne spp. have also been regularly associated with damage in the acerola cherry (Malpighia emarginata DC), guava (Psidium guajava L.), fig (Ficus carica L.), mango (Mangifera indica L.), kiwi (Actinidia chinensis Planch.) and grape (Vitis vinifera L.) (Junqueira et al., 1999; Paula et al., 2011; Martins et al., 2013; Cavichioli et al., 2014; Souza et al., 2015a; Castro et al., 2016).

The lesion nematodes, Pratylenchus penetrans and Pratylenchus vulnus, are species that can also damage peach production, causing degeneration of the root system, predisposing the plant to infections caused by other phytopathogenic microorganisms, and are the primary causal agents of replant diseases in the peach, a problem characterised by the atrophy and yellowing of the plants, usually accompanied by root necrosis (Pinochet et al., 1993; Gomes \& Campos, 2003).

Evaluating the association of Peach Tree Short Life Syndrome with soil fertility in the orchard, Mayer et al. (2015) found that the occurrence of early death in the peach was not related to the chemical attributes of soil fertility. In turn, Carneiro et al. (1993) and Campos et al. (2002) did not show any correlation between the occurrence of short life syndrome and the age of the plants, the location of the plants in the orchard, individual plants or groups of plants, not even with the scion. On the other hand, the ring nematode Mesocriconema xenoplax (Raski) Loof, has been associated with Peach Tree Short Life Syndrome (PTSL), whose symptoms are usually identified at the end of the dormancy period, and are characterised by a reduction or paralysation of growth and a reduction or lack of budding and flowering, leading to the death of the plants (Reddy et al., 2014). Parasitism by M. xenoplax in the peach tree causes darkening of the root system, followed by destruction of the tissue and atrophy of the roots (Kuhn et al., 2015), resulting in production problems, especially in Rio Grande do Sul, as it occurs almost everywhere stone fruits are cultivated (Mayer \& Ueno, 2012; Carneiro et al., 1993).

In Brazil, in addition to little being known about the population dynamics of phytonematodes associated with the cultivation of stone fruit, there is no registered nematicide for these crops (Agrofit, 2018), so genetic resistance and crop rotation are the most sustainable, effective and economical practices to suppress or reduce the damage caused by these root parasites (Walters et al., 2008; Pinochet et al., 1996; Salesses et al., 1995). Adopting such practices are important during the initial establishment and productive life of the orchards, particularly in areas with a history of parasitic nematodes.

Faced with this problem, the aim of the present study was to carry out a search for phytonematodes to verify the abundance and frequency of nematodes present in the rhizosphere and roots of nine peach rootstocks in an orchard at eight years of age.

\section{Method}

Prospecting for nematodes was carried out in an orchard located at the Palma Agricultural Centre of the Federal University of Pelotas-UFPel, in the district of Capão do Leão, Rio Grande do Sul, Brazil (31 ${ }^{\circ} 52^{\prime} 00^{\prime \prime}$ S, 52 $22^{\circ} 1^{\prime 2} 24^{\prime \prime}$ W, altitude $40 \mathrm{~m}$ ).

The soil in the orchard is moderately deep, with an average texture in the A horizon and a clayey texture in the B horizon, and is classified as a typic dystrophic Red-Yellow Argisol (Souza et al., 2017c). The mean cold accumulation in the region, below $7.2^{\circ} \mathrm{C}$, is around 400 hours, the mean annual rainfall is $1,367 \mathrm{~mm}$, and the mean annual minimum and maximum temperatures are $13.8^{\circ} \mathrm{C}$ and $22.9^{\circ} \mathrm{C}$ respectively (EAP, 2018).

The nematological survey was carried out on two strips of land, one adjacent to the other, forming contiguous lines. The first (1) strip corresponds to an orchard of the Chimarrita and Maciel cultivars grafted onto eight rootstocks of Prunus spp. obtained from seeds of cultivars of known origin. The second (2) strip corresponds to an orchard of the Maciel cultivar grafted onto rootstocks obtained from stones from the canning industry, and therefore of no known origin, identified only as 'Industry'. Both orchards are eight years of age. 
A total of 92 soil and root samples were collected in Strip 1, containing Prunus persica rootstocks identified as 'Viamão', 'Capdeboscq', 'Aldrighi', 'Tsukuba', 'Okinawa', 'Nemaguard' and 'Flordaguard', as well as 'Umezeiro' (Prunus mume), all grafted with the Chimarrita and Maciel cultivars. In Strip 2, the rootstock identified as 'Industry' was grafted with the Maciel cultivar, from which 50 soil and root samples were collected. In both strips, planting was at a spacing of $5.0 \times 1.5 \mathrm{~m}$.

Soil and root collections were made in the canopy projection area, at a depth of approximately $30 \mathrm{~cm}$, discarding the top five centimetres of soil. The samples were packed in plastic bags, identified and sent to the Laboratory of Plant Molecular Physiology of the Federal University of Pelotas, Capão do Leão, Rio Grande do Sul.

To extract the soil nematodes, $250 \mathrm{~mL}$ were processed following the methodology proposed by Jenkins, (1964). For analysis of the roots, samples weighing $10 \mathrm{~g}$ were processed as per the extraction method described by Hussey and Barker (1973). The extracted nematodes were collected in plastic containers. The nematodes were counted using a Peters slide under an optical microscope. Temporary slides were prepared to identify the nematodes at the genus level, using the Nickle (1991) and Tihohod (1997) keys for this step.

After identifying the nematode populations extracted from the soil and root samples, the mean abundance of nematodes in the soil $(\mathrm{Sa})$ and roots $(\mathrm{Ra})$ was calculated, determined from the average number of taxa in the collected samples. The relative abundance (Ra\%) in the soil and roots was also calculated as per Norton (1978), cited by Silva et al. (2008), with the formula $\mathrm{Ra} \%=(\mathrm{A} \times 100) / \mathrm{N}$, where $A$ is the number of individuals of a given taxon in the sample and $N$ corresponds to the total number of phytoparasitic nematodes in the sample; the relative frequency $(\mathrm{Rf} \%)$ was calculated with the formula $\mathrm{Rf} \%=(\mathrm{na} \times 100) / \mathrm{Na}$, where $n a$ represents the number of samples in which a given nematode taxon occurred and $\mathrm{Na}$ is the total number of samples collected in a given rootstock.

\section{Results and Discussion}

Thirteen nematode genera were identified in the soil and root samples: Meloidogyne spp., Pratylenchus spp., Helicotylenchus spp., Mesocriconema spp., Trichodorus spp., Longydorus spp., Tylenchorchynchus spp., Hemiciclyophora spp., Xiphinema spp., Tylenchulus spp., Dorylaimus spp., Rotylenchulus spp. and Mononchus spp. (Table 1). However, only the genera Mesocriconema spp., Pratylenchus spp. and Meloidogyne spp. are considered more aggressive in the peach (Walters et al., 2008; Pinochet et al., 1996; Carneiro et al., 1993). Forer et al. (1983) report that Xiphinema spp., at high population densities, may contribute to the decline of Prunus spp. plants, being associated with the transmission of Tomato Ringspot Virus in peach and cherry trees.

Table 1. Nematodes associated with nine peach rootstocks, expressed for mean nematode abundance in $250 \mathrm{~mL}$ of soil $(\mathrm{Sa})$ or $10 \mathrm{~g}$ of roots $(\mathrm{Ra})$, relative abundance in the roots and soil ( $\mathrm{Ra} \% \mathrm{R}$ and $\mathrm{Ra} \% \mathrm{~S}$ ) and relative frequency in the roots and soil (Rf\% S and Rf\% R). Capão do Leão, Rio Grande do Sul, November 2017

\begin{tabular}{|c|c|c|c|c|c|c|c|c|c|c|c|c|c|c|c|c|c|c|}
\hline \multirow{2}{*}{ Genus } & \multicolumn{6}{|c|}{ Viamão } & \multicolumn{6}{|c|}{ Tsukuba } & \multicolumn{6}{|c|}{ Nemaguard } \\
\hline & $\mathrm{Sa}$ & $\mathrm{Ra}$ & $\mathrm{Ra} \% \mathrm{~S}$ & $\mathrm{Ra} \% \mathrm{R}$ & $\mathrm{Rf} \% \mathrm{~S}$ & $\mathrm{Rf} \% \mathrm{R}$ & $\mathrm{Sa}$ & $\mathrm{Ra}$ & $\mathrm{Ra} \% \mathrm{~S}$ & $\mathrm{Ra} \% \mathrm{R}$ & $\mathrm{Rf} \% \mathrm{~S}$ & $\mathrm{Rf} \% \mathrm{R}$ & $\mathrm{Sa}$ & $\mathrm{Ra}$ & $\mathrm{Ra} \% \mathrm{~S}$ & $\mathrm{Ra} \% \mathrm{R}$ & $\mathrm{Rf} \% \mathrm{~S}$ & $\mathrm{Rf} \% \mathrm{R}$ \\
\hline Meloidogyne & 407.09 & 1111.77 & 100.00 & 100.00 & 21.07 & 57.54 & 8.50 & 0.00 & 60.00 & 00.00 & 1.30 & 0.00 & 27.45 & 6.27 & 36.36 & 27.27 & 11.77 & 2.69 \\
\hline Pratylenchus & 6.72 & 3.27 & 18.18 & 18.18 & 0.35 & 0.02 & 29.80 & 0.30 & 40.00 & 10.00 & 6.06 & 0.06 & 9.50 & 0.09 & 18.18 & 9.09 & 4.09 & 0.04 \\
\hline Helicotylenchus & 303.27 & 22.09 & 72.72 & 72.72 & 15.69 & 1.14 & 369.40 & 4.40 & 90.00 & 20.00 & 75.18 & 0.89 & 128.64 & 1.63 & 72.72 & 9.09 & 55.19 & 0.70 \\
\hline Mesocriconema & 23.63 & 30.72 & 9.09 & 0.00 & 1.22 & 1.59 & 13.30 & 3.30 & 20.00 & 20.00 & 2.70 & 0.67 & 7.72 & 1.90 & 27.27 & 18.18 & 3.31 & 0.82 \\
\hline Trichodorus & 5.09 & 0.00 & 9.09 & 0.00 & 0.26 & 0.00 & 12.10 & 0.30 & 40.00 & 10.00 & 2.46 & 0.06 & 8.18 & 0.54 & 9.09 & 9.09 & 3.51 & 0.23 \\
\hline Longidorus & 0.00 & 0.00 & 0.00 & 0.00 & 0.00 & 0.00 & 0.00 & 0.00 & 0.00 & 0.00 & 0.00 & 0.00 & 1.63 & 0.00 & 9.09 & 0.00 & 0.70 & 0.00 \\
\hline Tilenchorchynchus & 1.64 & 0.00 & 9.09 & 0.00 & 0.08 & 0.00 & 16.50 & 1.80 & 40.00 & 10.00 & 3.35 & 0.36 & 8.72 & 0.00 & 27.27 & 0.00 & 3.74 & 0.00 \\
\hline Mononchus & 0.00 & 0.00 & 0.00 & 0.00 & 0.00 & 0.00 & 10.20 & 0.00 & 20.00 & 0.00 & 2.07 & 0.00 & 1.63 & 0.00 & 9.09 & 0.00 & 0.70 & 0.00 \\
\hline Hemiciclyophora & 0.00 & 0.00 & 0.00 & 0.00 & 0.00 & 0.00 & 0.00 & 0.00 & 0.00 & 0.00 & 0.00 & 0.00 & 1.63 & 0.00 & 9.09 & 0.00 & 0.70 & 0.00 \\
\hline Xiphinema & 0.00 & 0.00 & 0.00 & 0.00 & 0.00 & 0.00 & 0.00 & 0.00 & 0.00 & 0.00 & 0.00 & 0.00 & 5.09 & 1.64 & 27.27 & 9.09 & 2.18 & 0.70 \\
\hline Tylenchus & 6.09 & 0.00 & 27.27 & 0.00 & 0.31 & 0.00 & 2.10 & 0.10 & 10.00 & 10.00 & 0.43 & 0.02 & 13.09 & 0.82 & 27.27 & 18.18 & 5.61 & 0.35 \\
\hline Dorylaimus & 5.09 & 0.00 & 9.09 & 0.00 & 0.26 & 0.00 & 10.10 & 0.12 & 30.00 & 10.00 & 2.05 & 0.02 & 3.27 & 0.12 & 18.18 & 9.09 & 1.40 & 0.03 \\
\hline Rotylenchulus & 2.36 & 3.27 & 9.09 & 9.09 & 0.12 & 0.17 & 7.50 & 0.00 & 10.00 & 0.00 & 1.53 & 0.00 & 3.45 & 0.00 & 18.18 & 0.00 & 1.48 & 0.00 \\
\hline
\end{tabular}


Table 1. Continued

\begin{tabular}{|c|c|c|c|c|c|c|c|c|c|c|c|c|c|c|c|c|c|c|}
\hline \multirow{2}{*}{ Genus } & \multicolumn{6}{|c|}{ Capdebosq } & \multicolumn{6}{|c|}{ Umezeiro } & \multicolumn{6}{|c|}{ Aldrighi } \\
\hline & $\overline{\mathrm{Sa}}$ & $\mathrm{Ra}$ & $\mathrm{Ra} \% \mathrm{~S}$ & $\mathrm{Ra} \% \mathrm{R}$ & Rf\%S & $\overline{R f \% R}$ & $\mathrm{Sa}$ & $\mathrm{Ra}$ & $\mathrm{Ra} \% \mathrm{~S}$ & $\mathrm{Ra} \% \mathrm{R}$ & $\mathrm{Rf} \% \mathrm{~S}$ & $\overline{R f \% R}$ & $\mathrm{Sa}$ & $\mathrm{Ra}$ & $\mathrm{Ra} \% \mathrm{~S}$ & $\mathrm{Ra} \% \mathrm{R}$ & $\mathrm{Rf} \% \mathrm{~S}$ & $\overline{R f \% R}$ \\
\hline Meloidogyne sp. & 587.87 & 1209.92 & 100.00 & 100.00 & 27.83 & 57.28 & 35.00 & 0.00 & 25.00 & 0.00 & 19.90 & 0.00 & 74.50 & 155.33 & 83.33 & 83.33 & 14.06 & 29.31 \\
\hline Pratylenchus sp. & 4.67 & 0.00 & 16.66 & 0.00 & 0.22 & 0.00 & 0.00 & 0.00 & 0.00 & 0.00 & 0.00 & 0.00 & 3.58 & 0.00 & 16.66 & 0.00 & 0.68 & 0.00 \\
\hline Helicotylenchus & 116.58 & 22.41 & 75.00 & 66.66 & 5.52 & 1.06 & 98.25 & 0.00 & 87.50 & 0.00 & 55.86 & 0.00 & 178.08 & 48.50 & 83.33 & 83.33 & 33.69 & 9.15 \\
\hline Mesocriconema & 37.33 & 41.25 & 58.33 & 58.33 & 1.77 & 1.95 & 0.00 & 0.00 & 0.00 & 0.00 & 0.00 & 0.00 & 64.08 & 66.80 & 16.66 & 16.66 & 0.77 & 1.29 \\
\hline Trichodorus & 18.41 & 10.66 & 50.00 & 16.66 & 0.87 & 0.50 & 9.00 & 0.00 & 12.50 & 0.00 & 5.12 & 0.00 & 4.08 & 0.00 & 16.66 & 0.00 & 0.77 & 0.00 \\
\hline Longidorus & 0.00 & 0.00 & 0.00 & 0.00 & 0.00 & 0.00 & 12.12 & 0.00 & 25.00 & 0.00 & 6.89 & 0.00 & 0.00 & 0.00 & 0.00 & 0.00 & 0.00 & 0.00 \\
\hline Tilenchorchynchus & 23.16 & 11.33 & 58.33 & 33.33 & 1.10 & 0.54 & 0.00 & 0.00 & 0.00 & 0.00 & 0.00 & 0.00 & 6.50 & 4.50 & 16.66 & 16.66 & 1.23 & 0.85 \\
\hline Mononchus & 2.33 & 0.00 & 8.33 & 0.00 & 0.11 & 0.00 & 5.75 & 0.00 & 25.00 & 0.00 & 3.27 & 0.00 & 4.50 & 0.00 & 8.33 & 0.00 & 0.85 & 0.00 \\
\hline Hemiciclyophora & 0.00 & 0.00 & 0.00 & 0.00 & 0.00 & 0.00 & 0.00 & 0.00 & 0.00 & 0.00 & 0.00 & 0.00 & 0.00 & 0.00 & 0.00 & 0.00 & 0.00 & 0.00 \\
\hline Xiphinema & 3.75 & 0.00 & 16.66 & 0.00 & 0.18 & 0.00 & 2.37 & 0.00 & 12.50 & 0.00 & 1.35 & 0.00 & 0.00 & 0.00 & 0.00 & 0.00 & 0.00 & 0.00 \\
\hline Tylenchus & 6.00 & 1.83 & 16.66 & 41.66 & 0.28 & 0.08 & 7.62 & 0.00 & 25.00 & 0.00 & 4.33 & 0.00 & 13.50 & 7.50 & 25.00 & 25.00 & 2.55 & 1.41 \\
\hline Dorylaimus & 10.41 & 2.25 & 41.66 & 8.33 & 0.49 & 0.07 & 5.75 & 0.00 & 12.50 & 0.00 & 3.26 & 0.00 & 15.83 & 0.00 & 33.33 & 0.00 & 2.99 & 0.00 \\
\hline Rotylenchulus & 1.75 & 0.00 & 8.33 & 0.00 & 0.08 & 0.00 & 0.00 & 0.00 & 0.00 & 0.00 & 0.00 & 0.00 & 2.58 & 0.00 & 8.33 & 0.00 & 0.49 & 0.00 \\
\hline
\end{tabular}

Table 1. Continued

\begin{tabular}{|c|c|c|c|c|c|c|c|c|c|c|c|c|c|c|c|c|c|c|}
\hline \multirow{2}{*}{ Genus } & \multicolumn{6}{|c|}{ Okinawa } & \multicolumn{6}{|c|}{ Flordguard } & \multicolumn{6}{|c|}{ Industry } \\
\hline & $\mathrm{Sa}$ & $\mathrm{Ra}$ & $\mathrm{Ra} \% \mathrm{~S}$ & $\mathrm{Ra} \% \mathrm{R}$ & $\mathrm{Rf} \% \mathrm{~S}$ & $\mathrm{Rf} \% \mathrm{R}$ & $\mathrm{Sa}$ & $\mathrm{Ra}$ & $\mathrm{Ra} \% \mathrm{~S}$ & $\mathrm{Ra} \% \mathrm{R}$ & $\mathrm{Rf} \% \mathrm{~S}$ & $\mathrm{Rf} \% \mathrm{R}$ & $\mathrm{Sa}$ & $\mathrm{Ra}$ & $\mathrm{Ra} \% \mathrm{~S}$ & $\mathrm{Ra} \% \mathrm{R}$ & $\mathrm{Rf} \% \mathrm{~S}$ & $\mathrm{Rf} \% \mathrm{R}$ \\
\hline Meloidogyne & 39.83 & 0.00 & 50.00 & 0.00 & 24.09 & 0.00 & 38.84 & 6.00 & 76.92 & 46.15 & 16.91 & 2.61 & 38.22 & 63.20 & 64.00 & 80.00 & 3.20 & 3.65 \\
\hline Pratylenchus & 2.08 & 0.00 & 8.33 & 0.00 & 1.26 & 0.00 & 0.00 & 0.00 & 0.00 & 0.00 & 0.00 & 0.00 & 3.88 & 4.80 & 18.00 & 18.00 & 0.32 & 0.40 \\
\hline Helicotylenchus & 99.08 & 0.00 & 83.33 & 0.00 & 59.92 & 0.00 & 112.61 & 1.38 & 76.92 & 7.69 & 50.04 & 0.60 & 161.54 & 251.52 & 90.00 & 90.00 & 13.52 & 21.05 \\
\hline Mesocriconema & 0.00 & 0.00 & 0.00 & 0.00 & 0.00 & 0.00 & 1.53 & 0.00 & 7.69 & 0.00 & 0.67 & 0.00 & 171.02 & 365.74 & 76.00 & 84.00 & 25.94 & 32.24 \\
\hline Trichodorus & 2.00 & 0.00 & 8.33 & 0.00 & 1.20 & 0.00 & 11.76 & 0.00 & 23.07 & 0.00 & 5.12 & 0.00 & 17.72 & 34.80 & 40.00 & 40.00 & 1.48 & 2.91 \\
\hline Longidorus & 0.00 & 0.00 & 0.00 & 0.00 & 0.00 & 0.00 & 0.00 & 0.00 & 0.00 & 0.00 & 0.00 & 0.00 & 7.12 & 0.00 & 22.00 & 0.00 & 0.59 & 0.00 \\
\hline Tilenchorchynchus & 6.00 & 0.00 & 16.66 & 0.00 & 3.62 & 0.00 & 19.23 & 0.00 & 46.15 & 0.00 & 8.37 & 0.00 & 33.20 & 61.20 & 64.00 & 64.00 & 2.78 & 5.12 \\
\hline Mononchus & 1.75 & 0.00 & 8.33 & 0.00 & 1.06 & 0.00 & 3.46 & 0.00 & 15.38 & 0.00 & 1.51 & 0.00 & 5.06 & 0.00 & 14.00 & 0.00 & 0.42 & 0.00 \\
\hline Hemiciclyophora & 0.00 & 0.00 & 0.00 & 0.00 & 0.00 & 0.00 & 0.00 & 0.00 & 0.00 & 0.00 & 0.00 & 0.00 & 0.00 & 0.00 & 0.00 & 0.00 & 0.00 & 0.00 \\
\hline Xiphinema & 0.00 & 0.00 & 0.00 & 0.00 & 0.00 & 0.00 & 2.92 & 0.00 & 15.38 & 0.00 & 1.30 & 0.00 & 7.54 & 25.80 & 22.00 & 22.00 & 0.63 & 2.20 \\
\hline Tylenchus & 4.50 & 0.00 & 16.66 & 0.00 & 2.72 & 0.00 & 21.38 & 2.76 & 23.07 & 15.38 & 9.31 & 1.21 & 7.48 & 15.20 & 14.00 & 12.00 & 0.62 & 1.27 \\
\hline Dorylaimus & 8.00 & 0.00 & 16.66 & 0.00 & 4.83 & 0.00 & 7.69 & 0.00 & 23.07 & 0.00 & 3.35 & 0.00 & 4.56 & 8.00 & 12.00 & 8.00 & 0.38 & 0.70 \\
\hline Rotylenchulus & 2.08 & 0.00 & 8.33 & 0.00 & 1.26 & 0.00 & 0.00 & 0.00 & 0.00 & 0.00 & 0.00 & 0.00 & 2.00 & 2.00 & 6.00 & 6.00 & 0.17 & 0.43 \\
\hline
\end{tabular}

Phytonematodes can reduce the vigour and productivity of a wide range of crops (Anwar et al., 2012; Ngele \& Kalu, 2015; Singh \& Kumar, 2015). When associated with other factors, they may lead to a decline and early death in stone fruits, especially the peach tree (Forer et al., 1983; Beckman et al., 2008; Walters et al., 2008). Mayer et al. (2015) found that the occurrence of PTSL has been increasing significantly in the peach orchards of Rio Grande do Sul, Brazil in recent decades, attributing part of the effect to the type of rootstock used, soil fertility and the presence of phytonematodes, especially M. xenoplax.

Among the nematodes that were identified, the genus Meloidogyne spp. was recorded in the roots of six (66.66\%) of the nine peach rootstocks under evaluation, whereas in the soil samples, this genus of nematodes was present in the rhizosphere of all nine rootstocks (Table 1). Meloidogyne spp. had the highest relative abundance in the soil and roots of the 'Capdeboscq' rootstock, with a mean of $587.87 \mathrm{nem} / 250 \mathrm{~mL}$ soil (SA) and $1209.92 \mathrm{nem} / 10$ g roots (RA), followed by the 'Viamão' rootstock, with a value for SA and RA of 407.09 and 1111.77 respectively (Table 1).

The Aldrighi cultivar had the third largest population abundance for Meloidogyne spp., with $74.50 \mathrm{nem} / 250 \mathrm{~mL}$ soil and $155.33 \mathrm{nem} / 10 \mathrm{~g}$ roots (Table 1). The abundance and relative frequency of Meloidogyne spp., in the soil and roots followed the same order of magnitude, being greater in 'Capdeboscq', followed by 'Viamão' and 'Aldrighi'.

Comparing the values for mean abundance of Meloidogyne spp., in the roots (RA) of the rootstocks, it was found that the Flordaguard and Nemaguard cultivars, considered important sources of resistance to root-knot nematodes (Paula et al., 2011), had a value for RA that was 99\% less than that registered in 'Capdeboscq', which is a genotype that is still used as rootstock in some nurseries, but which has been proved to be susceptible to Meloidogyne spp. (Fachinello et al., 2000; Paula et al., 2011). Also for Meloidogyne spp., it was found that 'Flordaguard' and 'Nemaguard' presented a higher RfS in relation to the RfR, of $84.56 \%$ and $77 \%$ respectively. 
On the other hand, in the susceptible cultivars Capdeboscq, Viamão and Aldrighi, the RfR was higher in relation to the RfS. The presence of this genus of nematode was not recorded in the roots (Ra) of the other rootstocks considered resistant to root-knot nematodes, 'Okinawa', 'Umezeiro' and 'Tsukuba' (Table 1).

Mesocriconema spp., was the second phytoparasite in terms of Sa and Ra. The greatest values for Sa and Ra were recorded in the 'Industry' rootstock (171.01 and 365.75 respectively), followed by the 'Adrighi', 'Capdeboscq' and 'Viamão' rootstocks (Table 1). Although Peach Tree Short Life Syndrome (PTSL) has been attributed to the joint action of biotic, soil and climate factors (Okie et al., 1987), the greater frequency and intensity of damage in the peach has shown a direct relationship to the presence of high populations of the ring nematode (M. xenoplax) (Nyczepir et al., 1988). As a consequence, it can be seen that the 'Industry' rootstock, produced from a mixture of the seed of several scions, has greater susceptibility to the ring nematode in relation to the other rootstocks under evaluation.

While Meloidogyne spp. displayed greater relative abundance and frequency in the 'Capdeboscq', 'Viamão' and 'Aldrighi' rootstocks in descending order of magnitude, for Mesocriconema spp., the greatest abundance and relative frequency were recorded in 'Industry', followed by 'Capdeboscq' and 'Aldrighi'. The 'Viamão' rootstock, although proving to be very susceptible to Meloidogyne, showed values for relative abundance and frequency for Mesocriconema spp. that were lower than those recorded in the 'Nemaguard' and 'Tsukuba' rootstocks (Table 1).

In the 'Flordaguard', 'Okinawa' and 'Umezeiro' rootstocks, Mesocriconema spp. had a value for Sa of 1.53, 0.0 and 0.0 respectively, whereas the Ra was zero in all three rootstocks, suggesting that these cultivars are not preferred hosts (Table 1), compared to the other rootstocks under evaluation.

When comparing the principal phytonematodes that occur associated with the nine prunus rootstocks being evaluated, Pratylenchus was recorded at a lower frequency and abundance in the soil and roots in relation to Meloidogyne and Mesocriconema. Pratylenchus spp. showed a greater abundance in the soil of the Tsukuba (29.80), Nemaguard (9.50), Viamão (6.72), Capdeboscq (4.87) and Industry cultivars (3.88). On the other hand, the greatest abundance in the roots (RA) was recorded in Industry (4.80) and Viamão (3.27), while in the other genotypes the RA was less than 1.0 or null.

The presence of Xiphinema was registered in the rhizosphere of the 'Nemaguard', 'Capdeboscq', 'Umezeiro', 'Flordaguard' and 'Industry' rootstocks, with values for Sa of 1.63, 3.75, 2.37, 2.92 and 7.54 respectively. However, when analysing the roots, the highest value for Ra was recorded in 'Industry' (25.8), followed by 'Nemaguard' (1.64), with Xiphinema spp., not being identified in the other rootstocks under evaluation. Specifically in the 'Industry' rootstock, Xiphinema had a value for Sa and Ra that were respectively 48.5 and $81.4 \%$ higher in relation to Pratylenchus spp.

In the rhizosphere and roots of the nine Prunus rootstocks under evaluation, most noticeable was the presence of phytoparasitic nematodes of the genera Meloidogyne spp. and Mesocriconema spp., which are considered the most important in relation to their potential to cause crop damage. Evaluating the incidence of phytonematodes in seven rootstocks in peach orchards in southern Illinois, USA, Walters et al. (2008) reported the occurrence of 11 species belonging to nine genera, with the phytonematodes Meloidogyne spp., Mesocriconema spp., Pratylenchus spp., and Xiphinema spp., having the greatest contribution to plant decline and reduced production.

In Rio Grande do Sul, there is still little information on the diversity, and few studies of the population levels of parasitic nematodes in relation to peach rootstock, except for some records of the presence of certain genera, such as Meloidogyne spp., and Mesocriconema spp. (Carneiro et al., 1993; Rossi, 2002; Gomes et al., 2010; Gomes et al., 2014).

Within the genus Prunus, there is great variability for resistance to root-knot nematodes (Pinochet et al., 1996, Esmenjaud et al., 1997; Rossi, 2002; Felipe, 2009; Paula et al., 2011; Souza et al., 2014). Resistance to Meloidogyne is relatively easy to transfer by hybridisation and is apparently determined by one or a few dominant genes (Marull et al., 1994), so sources of resistance when available can be used to control the damage caused by this nematode.

Different species of the genus Meloidogyne have been considered the most important cause of damage, not only in peach trees (Marull et al., 1994; Pinochet et al., 1996; Gomes et al., 2009; Paula et al., 2011), but also in a wide range of fruit and vegetable species (Anwar et al., 2012; Ngele \& Kalu, 2015; Singh \& Kumar, 2015). Meloidogyne spp. induce the formation of galls in the roots, restricting water and nutrient absorption and plant growth, besides predisposing the plant to attack by other pathogens. In the present study, it was found that 
'Capdeboscq', 'Viamão', 'Aldrighi' and 'Industry' are good hosts to this nematode; the use of these rootstocks in areas infested with Meloidogyne spp. should therefore be avoided.

Based on the results, it can be seen that the 'Okinawa', 'Tsukuba' and 'Umezeiro' rootstocks displayed low relative abundance and low relative frequency in the soil for Meloidogyne spp., while there was no incidence or reproduction of the nematode in the root samples. Although 'Nemaguard' and 'Flordaguard' are sources of resistance to Meloidogyne, they have a low Ra compared to the susceptible genotypes. This can be explained by the presence of different alleles that confer variability for resistance on the resistant rootstocks (Marull et al., 1994; Pinochet et al., 1996; Paula et al., 2011), inducing the preferential targeting by parasitic nematodes of the susceptible cultivars ('Capdeboscq', 'Viamão', 'Aldrighi' and 'Industry'), since the plots containing the plants of each rootstock are located side by side, at a spacing of $5.0 \times 1.5 \mathrm{~m}$.

Therefore, among the rootstocks under evaluation, the 'Okinawa', 'Tsukuba', 'Nemaguard', 'Flordaguard' and 'Umezeiro' cultivars can be alternatives when planting peach and plum orchards in areas with an incidence of Meloidogyne spp. Due to its good adaptation to the climate conditions in Brazil, 'Okinawa' is a good reference source of resistance to Meloidogyne spp., which was proven in the present study by the low abundance of this parasite in the soil samples and in the roots. Even so, the 'Okinawa' rootstock is little used in Brazil, but there are high expectations of its use being increased. On the other hand, 'Umezeiro' has also proved to be a good source of resistance to phytopathogenic nematodes, albeit also proving to be graft compatible with only a small number of peach cultivars.

In relation to $M$. xenoplax, studies and sources of resistance are far more scarce compared to those for Meloidogyne spp. In the USA, Mesocriconema is the main phytonematode associated with PTSL Syndrome. Although PTSL does not have a single cause, an increase in PTSL in the orchards of Rio Grande do Sul, Brazil, and more specifically in the region of Pelotas (the main area of production in the country), is directly related to the type of rootstock being used (Mayer et al., 2006), which is confirmed by the high incidence of phytonematodes in the root system of genotypes that were not selected for use as rootstock, such as the Viamão, Industry, Capdeboscq and Aldrighi cultivars.

Seeds of the Capdeboscq and Aldrighi cultivars were used for a long time in the production of rootstock due to the abundance of stones from the Brazilian canning industry. Capdeboscq seeds are still used in rootstock production because of the high rate of germination, the good graft compatibility of the seedlings with peach and plum cultivars, and the high level of vigour induced in the scions. However, with the development of new scions over the last three decades, waste stones from the peach-canning industry now comprise a mixture of genotypes with high genetic variability and high susceptibility to the different phytonematodes (Bianchi et al., 2014).

The 'Guardian ${ }^{\circledR}$ BY520-9' rootstock has shown good levels of tolerance not only to Mesocriconema but also to Meloidogyne incognita and M. javanica (Okie et al., 1994). However, the search for rootstock resistant to Mesocriconema, and with good graft compatibility with Prunus persica has not had much success. Studying the relationship between rootstock and PTSL syndrome, Mayer and Ueno (2012) identified a certain level of variability in peach rootstock to PTSL. Currently 'Sharpe ${ }^{\mathbb{B}}$, 'Guardian ${ }^{\mathbb{B}}$ ' and 'MP-29' are the principal rootstocks with resistance to the ring nematode (M. xenoplax) (Okie et al., 1994; Backman et al., 2008; Backman et al., 2012); however, the last two are protected rootstocks and not yet available for use in Brazil. In turn, 'Sharpe ${ }^{\circledR}$, has shown graft incompatibility and induced poor growth with some Brazilian peach cultivars (unpublished data).

In the present study, although at low population levels, Xiphinema spp. and Pratylenchus spp. were also identified in the soil and roots of some rootstocks, demonstrating the potential of these phytonematodes to cause economic damage in Prunus. Xiphinema spp. had a greater value for RA in the 'Industry' rootstock. The incidence of this phytonematode in the peach plants was reported by Walters et al. (2008), and it is among the principal parasitic phytoematodes associated with other fruit trees of the Rosaceae family (Brida et al., 2017; Souza et al., 2017). In turn, Pratylenchus spp. had a higher value for RA in the 'Industry' and 'Viamão' rootstocks. Compared to Meloidogyne and Mesocriconema, the levels of abundance and frequency of Xiphinema and Pratylenchus, although low, may be an indication that in the near future these nematodes might become another limiting factor associated with the cultivation of stone fruit if measures to contain them, such as the use of resistant rootstocks, are not adopted.

In Europe and North America, the lesion nematodes, P. penetrans and P. vulnus, are found in high abundance in Rosaceae plantations (Pruyne et al., 1994; Pinochet et al., 1996). In these areas, 'replant problems' have been reported, a disease of complex aetiology that occurs at sites of orchard replanting, involving nematodes, fungi, bacteria and abiotic factors (Dullahide et al., 1994; Walters et al., 2008). 
Helicotylenchus spp. was one of the nematode genera with the highest mean value for abundance identified in the soil samples, appearing associated with the root system, especially of the 'Industry' and 'Aldrighi' rootstocks. This nematode is often found in soil samples from several agricultural regions of the world, with a wide geographic distribution, and has been identified in association with several host plants and together with other nematodes, it is also responsible for a decline of the root system (Sharma et al., 1993; Palomares-Rius et al., 2017) there are however, no records of pathogenic importance in the peach tree.

Nematodes of other genera such as Trichodorus, Longidorus Tylenchus, Tilenchorchynchus and Rotylenchus have frequently been detected in peach orchards in southern Brazil, but at low population levels. Little is known about their damage to the peach tree, and their pathogenicity to the crop has not yet been confirmed (Gomes \& Campos, 2003); in addition, free-living nematodes, such as those of the genus Mononchus and Dorylaimus, are very common in samples of soil.

Based on the prospecting data, it was evident that in the 'Industry' (a mixture of scions), 'Capdeboscq', 'Aldrighi' and 'Viamão' rootstocks, the incidence of Mesocriconema spp. and Meloidogyne spp., is high compared to their occurrence recorded in the 'Tsukuba', 'Nemaguard', 'Flordaguard', 'Okinawa' and 'Umezeiro' rootstocks. This data reinforces the need for changes in the production system of Prunus rootstocks in Brazil, since according to Mayer et al. (2017), the tradition of using discarded stones from the peach-canning industry has been routine for decades.

The prospecting data and identification of the diversity and population level of phytonematodes in the present study makes an important contribution to guiding the work of genetic improvement of Prunus rootstock in Brazil, as well as alerting to the importance of the use of genotypes selected specifically for use as rootstocks. In addition, the data reinforce the need to avoid the use of peach stones discarded by the canning industry in the production of rootstocks.

\section{Conclusions}

Thirteen genera of nematode were identified associated with the rhizosphere and roots of nine peach rootstocks, including Meloidogyne spp., Mesocriconema spp., Pratylenchus spp., Xiphinema spp., Helicotylenchus spp., Trichodorus spp., Longidorus spp., Tylenchus spp., Tilenchorchynchus spp., Rotylenchus spp., Mononchus spp., Dorylaimus spp. and Hemiciclyophora spp.

The genera Meloidogyne spp. and Mesocriconema spp. were found at a higher population level in all the rootstocks under evaluation.

The 'Okinawa' and 'Umezeiro' rootstocks did not present any population levels of Meloidogyne spp. or Mesocriconema spp.

The soil and root samples of the 'Industry' rootstock displayed a high abundance and frequency of Mesocriconema spp., and therefore should not be recommended for use in rootstock production.

\section{References}

Agrofit. (2018). Sistema de agrotóxico fitossanitário: Controle de planta daninha. Retrieved from http://agrofit. agricultura.gov.br/agrofit_cons/!Ap_planta_consulta_cons

Almeida, C. B., Souza, A. G., Argenta, J. C., Fachinello, J. C., \& Bianchi, V. J. (2015) The effect of rootstocks on the vigor, yield, and fruit quality of Maciel peach trees. Revista Ciências Agrárias, 58, 301-307. https://doi.org/10.4322/rca.2011

Anwar, S. A., \& Mackenry, M. V. (2012). Incidence and population density of plant-parasitic nematodes infecting vegetable crops and associated yield losses in Punjab, Pakistan. Pakistan Journal of Zoology, 44, 327-333.

Backman, T. G., Chaparro, J. X., \& Sherman, W. B. (2008). 'Sharpe', a clonal plum rootstock for peach. HortScience, 43, 2236-2237. https://doi.org/10.21273/HORTSCI.43.7.2236

Backman, T. G., Chaparro, J. X., \& Sherman, W. B. (2012). 'MP-29', a clonal interspecific hybrid rootstock for peach. HortScience, 47, 128-131. https://doi.org/10.21273/HORTSCI.47.1.128

Beckman, T. G., Chaparro, J. X., \& Sherman, W. B. (2008). 'Sharpe', a clonal plum rootstock for peach. HortScience, 43, 2236-2237. https://doi.org/10.21273/HORTSCI.43.7.2236

Bianchi, V. J., Mayer, N. A., \& Castro, L. A. S. (2014). Produção de mudas. In M. C. B. Raseira, J. F. M. Pereira, \& F. L. C. Carvalho (Eds.), Pessegueiro (pp. 226-249). Brasília: Embrapa. 
Brida, A. L., Souza, A. G., Chaneiko, S. M., Tavares, L. N., Oliveira, P. G., \& Bianchi, V. J. (2017). Nematoides associados ao porta-enxerto Pyrus calleryana. Revista Congrega, 1, 1-10.

Campos, V. P., Campos, J. R., Silva, L. H. C. P., \& Dutra, M. R. (2002). Manejo de doenças causadas por nematoides em frutíferas. In L. Zambolim (Ed.). Manejo integrado: Fruteiras tropicais-doenças e pragas (pp. 185-238). Viçosa, MG: Suprema Gráfica e Editora.

Carneiro, R. M. D. G., Fortes, J. F., \& Almeida, M. R. A. (1993). Associação de Criconemella xenoplax com a morte do pessegueiro no Rio Grande do Sul. Nematologia Brasileira, 17, 122-131.

Castro, J. M. C., Ribeiro, J. M., Junior, P. M. R., Almeida, E. J., Sousa, A. D., \& Oliveira, P. G. (2016). Reprodução do nematoide-das-galhas da goiabeira em acessos de Psidium. Comunicata Scientiae, 8, 149-154. https://doi.org/10.14295/cs.v8i1.2652

Cavichioli, J. C., Garcia, M. J. M., Brida, A. L., \& Wilcken, S. R. S. (2014). Reação de aceroleira (Malpighia emarginata D.C.) À Meloidogyne enterolobii. Revista Brasileira de Fruticultura, 36, 156-160. https://doi.org/10.1590/0100-2945-429/13

Claverie, T., Chan, E., \& Patek, S. N. (2011). Modularity and scaling in fast movements: Power amplification in mantis shrimp. Evolution, 65, 443-461. https://doi.org/10.1111/j.1558-5646.2010.01133.x

Dullahide, S. R., Stirling, G. R., Nikulin, A., \& Stirling, A. M. (1994). The role of nematodes, fungi, bacteria, and abiotic factors in the etiology of apple replant problems in the Granite Belt of 19 Queesland. Australian Journal of Experimental Agriculture, 34, 1177-1182. https://doi.org/10.1071/EA9941177

EAP (Estação Agroclimatológica de Pelotas). (2018). Normais Climatológicas. Retrieved from http://www.cpact.embrapa.br/agromet/estacao/mensal.html

Esmenjaud, D., Minot, J. C., Voisin, R., Pinochet, J., Simard, M. H., \& Salesses, G. (1997). Differential response to root-knot nematodes in Prunus species and correlative genetic implications. Journal of Nematology, 29, 370-380.

Fachinello, J. C., Silva, C. A. P., Sperandio, C., Rodrigues, A. C., \& Strelow, E. Z. (2000). Resistência de porta-enxertos para pessegueiro e ameixeira aos nematóides causadores de galhas (Meloidogyne spp.). Ciência Rural, 30, 69-72.

FAO. (2018). Faostat: Production crops.

Felipe, A. J. (2009). 'Filinem', 'Garnem', and 'Monegro' Almond x Peach hybrid rootstocks. Hortscience, 44, 196-197.

Ferreira, R. V., Otoboni, C. E. M., Cruz, M. C., \& Goulart, S. L. (2007). Ocorrência de nematoide nas culturas da aceroleira, goiabeira e pessegueiro. Revista Científica Eletrônica de Agronomia, 7, 1-7.

Gomes, C. B., \& Campos, A. D. (2003). Sistema de Produção de Pêssego de Mesa na Região da Serra Gaúcha. Sistema de produção no. 3. Embrapa uva e vinho, Versão eletrônica.

Gomes, C. B., \& Carneiro, R. M. D. G. (2014). Nematoides fitoparasitas do pessegueiro. In M. C. B. Raseira, J. F. M. Pereira, \& F. L. C. Carvalho (Org.), Pessegueiro (1st ed., pp. 487-508). Brasília-DF: Embrapa.

Gomes, C. B., Campos, A. D., \& Costa, F. A. (2009). Levantamento de nematoides fitoparasitas associados a pomares de videira em declínio da Serra Gaúcha (p. 110). Embrapa Clima Temperado, Pelotas, RS. Boletim de Pesquisa e Desenvolvimento.

Gomes, C. B., Carvalho, J. G., \& Junior, E. E. B. (2010). Avaliação do potencial de coberturas verdes e de sistemas de rotações de cultura na supressão do nematoide anelado (Mesocriconema xenoplax) em pré-plantio ao pessegueiro. Revista Brasileira de Fruticultura, 32, 74-81. https://doi.org/10.1590/ S0100-29452010005000035

Hussey, R. S., \& Barker, K. R. A. (1973). Comparasion of methods of collecting inocula of Meloidogyne spp, including a new technique. Plant Disease Reporter, 57(12), 1025-1028.

IBGE (Instituto Brasileiro de Geografia e Estatística). (2018). Retrieved from http://www.ibge.gov.br/estadosat/ temas.php?sigla $=$ rs\&tema=lavourapermanente 2014

Jenkins, W. R. (1964). A rapid centrifugal-flotation technique for separation nematodes from soil. Plant Disease Reporter, 48, 692.

Junqueira, N. T. V., Anjos, J. R. N., Sharma, R. D., Sanzonovicz, C., \& Andrade, L. R. M. (1999). Doenças do maracujazeiro (pp. 83-115). Encontro de Fitopatologia, Viçosa: Editora UFV. 
Kuhn, P. R., Kulczynski, S. M., Bellé, C., Trevisan, R., \& Gomes, C. B. (2015). Suscetibilidade de espécies frutíferas, forrageiras e daninhas a duas populações de Mesocriconema xenoplax. Nematropica, 45, 279-286.

Lecouls, A. C., Salesses, G., Minot, J. C., Voisin, R., Bonnet, A., \& Esmenjaud, D. (1997). Spectrum of the Magenes for resistance to Meloidogyne spp. in Myrobalan plum. Theor Appl Genet, 95, 1325-1334. https://doi.org/10.1007/s001220050700

Martins, L. S. S., Musser, R. S., Souza, A. G., Resende, L. V., \& Maluf, W. R. (2013). Parasitismo de Meloidogyne enterolobii em espécies de Myrtaceae. Revista Brasileira de Fruticultura, 35, 77-484. https://doi.org/10.1590/S0100-29452013000200017

Marull, J., Pinochet, J., Felipe, A., \& Cenis, J. L. (1994). Resistance verification in Prunus selections to a mixture of 13 Meloidogyne isolates and resistance mechanisms of peach-almond hybrid to M. javanica. Fundamental and Applied Nematology, 17, 85-92.

Mayer, N. A., \& Ueno, B. (2012). A morte-precoce do pessegueiro e suas relações com porta-enxertos (p. 42). Pelotas: Embrapa Clima Temperado.

Mayer, N. A., Bianchi, V. J., Feldberg, N. P., \& Moriri, S. (2017). Advances in peach, nectarine and plum propagation. Revista Brasileira de Fruticultura, 39, 1-25. https://doi.org/10.1590/0100-29452017355

Mayer, N. A., Ueno, B., Silva, V. A. L., Valgas, R. A., \& Silveira, C. A. P. (2015). A morte precoce do pessegueiro associada à fertilidade do solo. Revista Brasileira de Fruticultura, 37, 773-787. https://doi.org/ 10.1590/0100-2945-156/14

Ngele, K. K., \& Kalu, U. N. (2015). Studies on different species of plant parasitic nematodes attacking vegetable crops grown in Afkipo North L.G.A., Nigeria. Direct Research Journal of Agriculture and Food Science, 3, 88-92.

Nickle, W. R. (1991). Manual of agricultural nematology (p. 1035). New York: Marcel Dekker.

Norton, D. C. (1978). Communities. In D. C. Norton (Ed.), Ecology of plant parasitic nematodes (pp. 59-79). New York: John Wiley.

Nyczepir, A. P., Backman, T. G., \& Reighard, G. L. (1999). Reproduction and development of Meloidogyne incognita and M. javanica on Guardian peach rootstock. Journal of Nematology, 31(3), 334-340.

Nyczepir, A. P., Reilly, C., Motsinger, R. E., \& Okie, W. R. (1988). Behavior, parasitism, morphology, and biochemistry of Criconemella xenoplax and C. ornata on peach. Journal of Nematology, 20, 40-46.

Okie, W. R., Beckman, T. G., Nyczepir, A. P., Reighard, G. L., Newall, W. C., \& Zehr, E. I. (1994). By520-9, a peach rootstock for the Southeastern United States that increases scion longevity. HortScience, 29, 705-706. https://doi.org/10.21273/HORTSCI.29.6.705

Okie, W. R., Nyczepir, A. P., \& Reilly, C. C. (1987). Screening of peach and other Prunus species for resistance to ring nematode in the greenhouse. Journal of the American Society for Horticultural Science, 112, 67-70.

Palomares-Rius, J. E., Escobar, C., Cabrera, J., Vovlas A., \& Castillo, P. (2017). Anatomical alterations in plant tissues induced by plant-parasitic nematodes. Frontier Plant Science, 8, 1-16. https://doi.org/10.3389/ fpls.2017.01987

Paula, L. A., Bianchi, V. J., Gomes, C. B., \& Fachinello, J. C. (2011). Reação de porta-enxertos de pessegueiro à Meloidogyne incognita. Revista Brasileira de Fruticultura, 33, 680-684. https://doi.org/10.1590/S010029452011000200043

Paula, L. A., Bianchi, V. J., Nogueira, L. R., Barros, W. S., \& Fachinello, J. C. (2011). Transferabilidade e ligação de marcadores moleculares em uma população de Prunus persica ('Capdeboscq' $\times$ 'Flordaguard'). Revista Brasileira Agrociência, 17, 321-325.

Pinochet, J., Anglès, M., Dalmay, E., Fernández, C., \& Felipe, A. (1996). Prunus rootstock evaluation to root-knot and lesion nematodes in Spain. Supplement to Journal of Nematology, 28, 616-623.

Pinochet, J., Fernández, E., Esmenjaud, D., \& Doucet, M. (1993). Effects of six Pratylenchus vulnus isolates on the growth of peach-almond hybrid and apple rootstocks. Journal of Nematology, 25, 843-848.

Pruyne, P. T., Merwin, I. A., Mullin, P. G., \& Gibson, D. M. (1994). Diagnosis of apple replant problems in New York orchand soils and evaluation of nematode suppressive cover crops. Acta Horticulturae, 17, 121-128. https://doi.org/10.17660/ActaHortic.1994.363.16 
Reddy, K. C., Andersen, E. C., Kruglyak, L., \& Kim, D. H. (2014). A polymorphism in NPR-1 is a behavioral determinant of pathogen susceptibility in C. elegans. Science, 323, 382-384. https://doi.org/10.1126/ science. 1166527

Rossi, C. E. (2002). Levantamento, reprodução e patogenicidade de nematoides a fruteiras de clima subtropical e temperado (p. 114). Tese de Doutorado, ESALQ: Piracicaba, São Paulo.

Salesses, G., Felipe, A., Esmenjaud, D., Pinochet, J., \& Fernándes, C. (1995). Avances en la selección de patrones de frutales de hueso frente a nematodos agalladores. Fruticultura Profesional, 2, 28-44.

Sharma, R. D., Silva, D. B., \& Castro L. H. R. (1993). Efeito de Helicotylenchus dihystera sobre trigo e ervilha cultivados em solos provenientes de três sistemas de preparo. Nematologia Brasileira, 17, 85-95.

Sherman, W. B., Lyrene, P. M., \& Sharpe, R. H. (1991). Flordaguard peach rootstock. HortScience, 26, 427-428. https://doi.org/10.21273/HORTSCI.26.4.427

Silva, R. A., Oliveira, C. M. G., \& Inomoto, M. M. (2008). Fauna de fitonematoides em áreas preservadas e cultivadas da floresta amazônica no Estado de Mato Grosso. Tropical Plant Pathology, 33, 204-211. https://doi.org/10.1590/S1982-56762008000300005

Singh, R., \& Kumar, U. (2015). Assessment of nematode distribution and yield losses in vegetable crops of Western Uttar Pradesh in India. International Journal of Science and Research, 4, 2812-2816.

Souza, A. G., Brida, A. L., Chaneiko, S. M., Tavares, L. N., Oliveira, P. G., Garcia, F. R. M., \& Bianchi, V. J. (2017b). Levantamento e correlação de nematoides na rizosfera de porta-enxerto 'Marubakaido'. Revista Congrega, 1, 1-10.

Souza, A. G., Chalfun, N. N., Musser, R. dos Santos., Fachinello, J. C., Campos, V. P., \& Souza, A. A. (2014a). Behavior of peach and mume rootstocks to the nematode Meloidogyne enterolobii. Revista Ciência Agrarias, 57, 108-113. https://doi.org/10.4322/rca.2014.002

Souza, A. G., Resende, L. V., Lima, I. P., \& Techio, V. H. (2015). Chromosome number and nuclear DNA amount in Psidium spp. resistant and susceptible to Meloidogyne enterolobii and its relation with compatibility between rootstocks and commercial varieties of guava tree. Plant Systematics and Evolution, 300, 312-317.

Souza, A. G., Smiderle, O. J., Muraro, R. E., \& Bianchi, V. J. (2017c). Morphophysiological quality of seedlings and grafted peach trees: Effects of nutrient solution and substrates. Recent Patents on Food, Nutrition \& Agriculture, 9, 010-018. https://doi.org/10.2174/2212798410666180508101641

Souza, A. G., Smiderle, O. J., Spinelli, V. M., Souza, R. O., \& Bianchi, V. B. (2017a). Optimization of germination and initial quality of seedlings of Prunus persica tree rootstocks. Journal of Seed Science, 39, 66-173. https://doi.org/10.1590/2317-1545v39n2171687

Souza, A. G., Smiderle, O. J., Spinelli, V. M., Souza, R. O., \& Bianchi, V. B. (2016). Correlation of biometrical characteristics of fruit and seed with twinning and vigor of Prunus persica rootstocks. Journal of Seed Science, 38, 322-328. https://doi.org/10.1590/2317-1545v38n4164650

Tihohod, D. (1997). Guia prático para a identificação de fitonematoides (p. 246). Jaboticabal: FCAV.

United State Department of Agriculture, National Agricultural Statistics Service. (USDA NASS). 2018. Fresh Peaches and Cherries: World Markets and Trade. Retrieved from https://apps.fas.usda.gov/psdonline/ circulars/StoneFruit.pdf

Walters, S. A., Bond, J. P., Russell, J. B., Taylor, B. H., \& Handoo, Z. A. (2008). Incidence and influence of plant-parasitic nematodes in southern Illinois peach orchards. Nematropica, 38, 63-74.

Zhao, S. U. S. (2017). Peach Producer Preference and Willingness to Pay for Fruit Attributes. HortScience, 1, 116-121. https://doi.org/10.21273/HORTSCI10966-16

\section{Copyrights}

Copyright for this article is retained by the author(s), with first publication rights granted to the journal.

This is an open-access article distributed under the terms and conditions of the Creative Commons Attribution license (http://creativecommons.org/licenses/by/4.0/). 